\title{
In vitro and in vivo Nematocidal Activity of Allium sativum and Tagetes erecta Extracts Against Haemonchus contortus
}

\author{
Allium sativum (Sarımsak) ve Tagetes erecta (Kadife Çiçeği) Özlerinin Haemonchus
}

contortus'a Karşı in-vitro ve in-vivo Nematisidal Etkisi

\author{
Josefina Palacios-Landín', Pedro Mendoza-de Gives', David Osvaldo Salinas-Sánchez², \\ María Eugenia López-Arellano', Enrique Liébano-Hernández', \\ Victor Manuel Hernández-Velázquez³, María Guadalupe Valladares-Cisneros ${ }^{4}$
}

\author{
${ }^{1}$ Centro Nacional de Investigación Disciplinaria en Parasitología Veterinaria, INIFAP-México, Department of Helminthology, Jiutepec, Morelos, México \\ ${ }^{2}$ Centro de Investigación en Biodiversidad y Conservación CIByC, UAEM, Cuernavaca, Morelos, México \\ ${ }^{3}$ Centro de Investigación en Biotecnología, Control de Plagas Agrícolas y Pecuarias, Cuernavaca, Morelos, México \\ ${ }^{4}$ Facultad de Ciencias Químicas e Ingeniería, Universidad Autónoma del Estado de Morelos, Cuernavaca, Morelos, México
}

\section{ABSTRACT}

Objective: In the Mexican ethno-medicine, a number of plants have shown a successful anthelmintic activity. This fact could be crucial to identify possible green anti-parasitic strategies against nematodes affecting animal production. This research evaluated the in vitro and in vivo nematocidal effects of two single and combined plant extracts: bulbs of Allium sativum (n-hexane) and flowers of Tagetes erecta (acetone). The in vivo assay evaluated the administration of extracts either individually or combined against Haemonchus contortus in experimentally infected gerbils. Methods: The in vitro larvicidal activity percentage (LAP) of A. sativum and T. erecta extracts against $H$. contortus (L3) was determined by means of individual and combined usage of the extracts. Similarly, the extracts were evaluated in terms of reduction in the parasitic population in gerbils infected with $\mathrm{H}$. contortus by individual and combined usage.

Results: The LAP at $40 \mathrm{mg} / \mathrm{mL}$ was $68 \%$ with A. sativum and $36.6 \%$ with T. erecta. The combination caused $83.3 \%$ mortality of parasites. The oral administration of $A$. sativum and T. erecta extracts at $40 \mathrm{mg} / \mathrm{mL}$, caused $68.7 \%$ and $53.9 \%$ reduction of the parasitic burden, respectively. Meanwhile, the combined effect of both extracts shown $87.5 \%$ reduction.

Conclusion: This study showed evidence about the effect of $A$. sativum and T. erecta plant extracts by means of individual and combined usage against H. contortus in in vitro and in vivo bioassays in artificially H. contortus-infected gerbils as a model. (Turkiye Parazitol Derg 2015; 39: 260-4)

Keywords: Allium sativum, Haemonchus contortus, Meriones unguiculatus (gerbil), Nematode mortality, Tagetes erecta

Received: 10.09 .2015

Accepted: 15.10 .2015

\section{Öz}

Amaç: Meksika etnik-tıpta, bazı bitkiler başarılı bir anthelmintik etki göstermektedirler. Bu gerçek, hayvan üretimini etkileyen nematodlara karşı, olası yeşil anti-parazitik stratejilerin belirlenmesi için önemli olabilir. Bu araştırma iki tek ve kombine bitki özlerinin, Allium sativum soğanları (n-hekzan) ve Tagetes erecta (aseton) çiçeklerinin, nematosidal etkisini in vitro ve in vivo olarak değerlendirmiştir. In vivo çalışmada, deneysel olarak etkilenen gerbillerde Haemonchus contortusa karşı, bitki özleri tek olarak ya da birlikte uygulanmıştır.

Yöntem: A. sativum ve T. erecta özlerinin $H$. contortusa $\left(L_{3}\right)$ karşı in vitro larvisidal etki yüzdesi (LEY), bitki özlerinin tek başına ve kombine olarak kullanılması ile belirlendi. Aynı şekilde bitki özleri, H. contortus ile infekte olmuş gerbillerdeki parazit popülasyonunu azaltması açısından, tek ve beraber kullanılarak değerlendirilmiştir.

Bulgular: $40 \mathrm{mg} / \mathrm{mL}$ 'deki LEY, A. sativum için \%68 ve T. erecta için \%36,6 olarak bulunmuştur. Kombinasyon \%83,3 oranında mortaliteye neden olmuştur. $40 \mathrm{mg} / \mathrm{mL}$ dozdaki bitki özlerinin oral olarak uygulanması ile parazit popülasyonu A. sativum için \%68,7 ve T. erecta için $\% 53,9$ azalmıştır. Aynı zamanda, kombine etkisi \% 87,5 olarak tespit edilmiştir.

Sonuç: Bu çalışma, bir model olarak, yapay olarak H. contortusdan infekte olan gerbillerle yapılan in vitro ve in vivo biyoanalizlerde, $A$. sativum ve $T$. erecta bitki özlerinin tek ve kombine olarak kullanılmasının H. contortusa karşı etkisini kanıtlamaktadır. (Turkiye Parazitol Derg 2015; 39: 260-4)

Anahtar Kelimeler: Allium sativum, Haemonchus contortus, Meriones unguiculatus (gerbil), Nematod mortalitesi, Tagetes erecta Geliş Tarihi: 10.09.2015

Kabul Tarihi: 15.10 .2015

Address for Correspondence / Yazışma Adresi: Dr. Pedro Mendoza-de Gives. E.mail: pedromdgives@yahoo.com DOI: 10.5152/tpd.2015.4523

(C) Copyright 2015 Turkish Society for Parasitology - Available online at www.tparazitolderg.org

CTelif hakkı 2015 Türkiye Parazitoloji Derneği - Makale metnine www.tparazitolderg.org web sayfasından ulaşılabilir. 


\section{INTRODUCTION}

Gastrointestinal parasitic nematodes (gin) are responsible for an important economic impact in ruminants (1). Particularly, Haemonchus contortus causes a severe damage on animal health because of its hematophagia habits. The immune system of young parasitized animals is dramatically diminished and they even can eventually die (2). Systematic deworming of animals using chemical anthelmintic drugs (CADs) is the most common method of gin control worldwide. Such a strategy reduces the parasitic burden in animals; however, there are a number of inconvenient factors that diminish the beneficial use of such drugs. One example is the anthelmintic resistance in the parasites that causes an inefficiency of the anthelmintic drugs. Also, once animals have been dewormed, some CADs are expelled into the environment in their bioactive form through feces or urine, creating a risk to non-target microorganisms (3).

Green technology offers an environmental friendly alternative. During the last decades, the use of natural bio-compounds obtained from plants with medicinal properties is gaining importance in human health. There are currently, a number plants extracts that have been commercialized worldwide (4). Similarly, plants and their products are being deeply studied searching for tools of control against animal parasitic nematodes. Many plants are currently being explored to identify possible candidates for control in animals of veterinary importance (5-10). Recently, two outstanding plants, Allium sativum and Tagetes erecta, have been identified and selected for investigating their green nematocidal activity.

A. sativum (garlic) is a member of the Liliaceae family and one of the most popular bulbs used worldwide to reduce various risk factors associated with several diseases, including activity against gin (11). Some bio-compounds obtained from garlic are allicin, allinin, ajoene, and diallylsulfide that are sulphured compounds.

T. erecta $L$ (marigold) is known as death flower and is a medicinal and ornamental plant; it is also used for its nematocide, cosmetic, and medicinal properties $(12,13)$. The plant $T$. erecta has been shown to contain quercetagetin, a glucoside of quercetagetin, phenolics, syringic acid, methyl-3, 5-dihydroxy-4-methoxybenzoate, quercetin, and thienyl and ethyl gallate $(13,14)$. The leaves are reported to be effective against bleeding piles, kidney troubles, muscular pain, ulcers, and wounds. Phytochemical studies of its different parts have resulted in the isolation of various chemical constituents such as flavonoids, carotenoids, and triterpenoids.

Their importance is being evaluated in the control of animal parasitic nematodes (15). The present research aimed to evaluate the in vitro and in vivo nematocidal effects of the plant extracts obtained from $A$. sativum and T. erecta (administered either individually or combined) against $H$. contortus as a green alternative of parasitic control.

\section{METHODS}

\subsection{Plant material}

The selection of plants was based on the ethno-botanical background (either scientific or empiric) and its usage in traditional medicine as de-wormer products. A. sativum vegetative material was obtained from the local market in the City of Cuernavaca, and $T$. erecta flowers were obtained from a rural field in the Municipality of Tixtla; both places are situated in the State of Morelos, Mexico. The A. sativum bulbs were peeled, and all coats were removed and finely sliced. In the case of $T$. erecta, the flowers were processed for extraction as follows: $n$-hexane for $A$. sativum and acetone for $T$. erecta by a maceration process at room temperature $(6,16,17)$.

\subsection{H. contortus infective larvae $\left(L_{3}\right)$}

The $H$. contortus isolate was originally obtained from a naturally infected sheep from "Las Margaritas" Experimental Sheep Farm (INIFAP) in Hueytamalco Municipality in the State of Puebla, Mexico. A H. contortus egg donor lamb was orally infected with an aqueous suspension containing 350 larvae/kg of body weight. Twenty days after infection, the presence of $\mathrm{H}$. contortus eggs in fecal samples was detected with the McMaster technique (18). Infective larvae were extracted from coprocultures using the Baermann funnel technique (18). Larvae were unsheathed following the technique described by López Aroche et al. (6). The total number of $\mathrm{L}_{3}$ in aqueous suspension was estimated by counting them in ten $10 \mathrm{ml}$ aliquot drops (19).

\subsection{Bioassays to determine the $50 \%$ lethal concentration ( $\mathrm{LC}_{50}$ )} Different extract concentrations of $A$. sativum $n$-hexane and $T$. erecta acetone extracts were evaluated to determine the $\mathrm{LC}_{50}$ by means of the individual and combined effects of both extracts. Initially, the solution of each extract at $40 \mathrm{mg} / \mathrm{mL}$ was prepared as a "stock solution." From this concentration, double dilutions were prepared to obtain the following concentrations: 40, 20, 10, $5,2.5,1.25$, and $0.625 \mathrm{mg} / \mathrm{mL}$. The assay was performed in 24-well tissue culture plates at $500 \mathrm{~mL}$ for three replicates. Proper controls (3\% tween-20 and 3\% fenbendazole and distilled water) were used, and the protocol cited by López-Aroche et al. was followed (6). Results were obtained by counting the number of live and dead $L_{3}$ in the wells and means of either live/dead larvae after $24 \mathrm{~h}$ and $72 \mathrm{~h}$ confrontation were recorded. $\mathrm{LC}_{50}$ was obtained using the POLO program (version 2003). The in vitro efficacy percentage of the extracts and $\mathrm{LC}_{50}$ were determined using the following formula:

Efficacy percentage $=\frac{\text { Alive }\left(L_{3}\right) \text { control }- \text { Alive }\left(L_{3}\right) \text { treated }}{\text { Alive }\left(L_{3}\right) \text { control }} \times 100$

Where, Alive $\left(L_{3}\right)$ Control=Mean of alive $\left(L_{3}\right)$ recovered from control group

Alive $\left(L_{3}\right)$ Treated $=$ Mean of alive $\left(L_{3}\right)$ recovered from treated group

\subsection{Experimental animals}

Forty-two male and female 3-month-old gerbils weighing an average of $40 \mathrm{~g}$ were obtained from a local bioterium. Animals were kept in metallic cages at $28-30^{\circ} \mathrm{C}(n=7)$, and a 2-week adaptation period was established to determine their health conditions. Presence of gin eggs in feces was diagnosed, and gin-positive gerbils were dewormed and other provided recommendations were followed according to de Jesús-Gabino et al. (17). 


\subsection{Assessing the in vivo oral administration of plant extracts in gerbils}

The optimum dose of $H$. contortus $\left(L_{3}\right)$ to achieve an infection in gerbils and the best administration route for the plant extracts were determined according to de Jesús-Gabino et al. (17). Gerbil groups were conformed as follows: I) distilled water, II) 3\% tween20 (in water), III) albendazol, IV) A. sativum extract, V) T. erecta extract, and $\mathrm{VI}$ ) both combined extracts. The extracts were administered at $40 \mathrm{mg} / \mathrm{mL}$ contained in $100 \mu \mathrm{L}$ volume (as a total dose). The animals were slaughtered 13 days post-infection. Necropsy was performed to obtain the stomach and to collect the nematodes presents in the gastric lumen. Then, nematodes were quantified to estimate the recovery average of parasites per group. The reduction percentage of parasitic burden attributed to the treatments was estimated using the following formula:

$$
\% E=\frac{X B-X A}{X B} \times 100
$$

Where, \%E=Reduction percentage

$X A=$ Mean of recovered parasites from the treated group

$\mathrm{XB}=$ Mean of recovered parasites from the control group

\subsection{Statistical analysis}

Data were analyzed using the Shapiro-Wilk statistical test $(P<0.0001)$. Data were transformed to square root for data normalizing $(P<0.6035)$ (20). After data normalizing, analysis of variance was used considering the average of recovered nematodes from different groups at necropsy as the dependent variable. Additionally, the minimum significance difference $(\alpha=0.05)$ was used as a multiple mean comparison to determine the difference between treatments using the Statistic Analysis System (21).

\section{RESULTS}

The in vitro median $\mathrm{LC}_{50}$ after $24 \mathrm{~h}$ and $72 \mathrm{~h}$ confrontation of $\mathrm{A}$. sativum $\mathrm{n}$-hexane extract with the nematode larvae was identified as $7.9 \mathrm{mg} / \mathrm{mL}$ and $3.8 \mathrm{mg} / \mathrm{mL}$, respectively. Meanwhile, the

Table 1. Total number and average of Haemonchus contortus $\left(L_{4}\right)$ recovered at necropsy of artificially infected gerbils after being treated with two plant extracts, either alone or combined

\begin{tabular}{|l|c|c|c|}
\hline Treatment & $\begin{array}{c}\text { Recovered } \\
\text { H. contortus }\left(\mathbf{L}_{\mathbf{4}}\right)\end{array}$ & $\begin{array}{c}\text { Average } \\
\mathbf{X}(\mathbf{( S D})\end{array}$ & $\begin{array}{c}\text { Reduction } \\
(\%)\end{array}$ \\
\hline Fenbendazole* $^{*}$ & 11 & $2.7( \pm 2.21)^{\mathrm{a}}$ & 97.5 \\
\hline $\begin{array}{l}\text { Allium sativum/ } \\
\text { Tagetes erecta }\end{array}$ & 83 & $11.8( \pm 5.9)^{\mathrm{b}}$ & 87.5 \\
\hline Allium sativum & 219 & $31.2( \pm 13)^{\mathrm{c}}$ & 68.7 \\
\hline Tagetes erecta & 308 & $44( \pm 21)^{\mathrm{d}}$ & 53.9 \\
\hline Tween-20 AL 3\% & 572 & $95.3( \pm 42.5)^{\mathrm{e}}$ & 10 \\
\hline Water & 749 & $107( \pm 58)^{\mathrm{f}}$ & 0 \\
\hline
\end{tabular}

*=Positive control; Values followed by a different letter indicate statistical differences $(P<0.05)$

$\mathrm{X}=$ Average; $\mathrm{SD}=$ Standar Deviation
T. erecta acetone extract showed a very low in vitro lethal activity against the nematode from which no $L_{50}$ was obtained. On the other hand, the $\mathrm{LC}_{50}$ for the extract combinations of both plants was $3.95 \mathrm{mg} / \mathrm{mL}$ at $24 \mathrm{~h}$ and $1.3 \mathrm{mg} / \mathrm{mL}$ at $72 \mathrm{~h}$ confrontation. The results of the in vivo assay of extracts, either individual or combined, are shown in Table 1, which includes the total number of recovered $L_{4}$ at necropsy of gerbils as well as the average and the reduction percentage of recovered nematodes. A reduction of $H$. contortus $\left(L_{4}\right)$ population of $68.7 \%$ and $53.9 \%$ were individually obtained with $A$. sativum and $T$. erecta, respectively. On the other hand, 87.5\% larvae reduction was obtained with the combined extracts. Similarly, larvae reduction percentages obtained with the controls fenbendazole, 3\% tween-20 (in water), and water were $97.5 \%, 10 \%$, and $0 \%$, respectively.

\section{DISCUSSION}

The A. sativum in vitro activity obtained in the present research (at $72 \mathrm{~h}$ ) can be considered important, particularly because it is a natural extract. Similarly, the low in vitro lethal activity was obtained with the T. erecta extract after $24 \mathrm{~h}$, and this percentage was increased at $72 \mathrm{~h}$ confrontation. The in vitro assays provide useful information about the lethal activity of organic plant extracts against gin infective larvae. However, the real effect of any plant extract as an anthelmintic compound is achieved through the in vivo assays (22). Both A. sativum and T. erecta individual extracts reduced the $L_{4}$ population in values higher than $50 \%$. The A. sativum in vivo efficacy in the present experiment showed that it can have a very good result, and it was very similar to the one obtained at $24 \mathrm{~h}$ in vitro confrontation. This efficacy is important because such a result was obtained only by administering the plant extract as a single alternative of control. Perhaps, such efficacy could increase using other vehicles or even other doses. The in vivo efficacy of $T$. erecta was very similar to the one obtained in the in vitro assay at $72 \mathrm{~h}$ confrontation. Perhaps there are similar cuticle molecules between the $L_{4}$ and $L_{5}$ evaluative stages and probably they share the same cuticle receptors susceptible to act as bio-compound targets. The fact that the $T$. erecta extract removed the parasitic burden by less than $50 \%$ could be considered a low activity compared with the regular anthelmintic drugs; nevertheless, it is an acceptable reduction for a natural plant extract. The combination of both extracts achieved a higher effect in reducing the gerbil parasitic burden (87.5\%). This study shows, for the first time, evidence about the anthelmintic effect of two plant extracts used, individually or combined, against $H$. contortus in artificially infected gerbils as an in vivo model of study. The different results obtained both in the in vitro assay and in the present in vivo assay could be due to the fact that the in vitro assay provides favorable conditions to allow the plant extracts to display their lethal nematocidal activity. In contrast, the in vivo assay has to overcome the gerbil physiological body barriers (temperature, $\mathrm{pH}$, enzymes, etc.) to express their anthelmintic effect. This result motivates a continued search for increasing the efficacy of these or other bio-compounds obtained from plant extracts, either individually or combined. Similarly, these and other plants and also other organic solvents could achieve a higher anthelmintic activity in gerbils with potential use in sheep. The use of organic extracts from a number of plants, using different solvents, has been evaluated against a wide variety of parasites. The Spigelia anthelmia 
ethanol extract showed $74 \%$ anthelmintic activity against Nippostrongylus brasiliensis in rats (23). In another study, the oral administration of an aqueous extract of Jazmin (Jasminum abyssinicum) leaves reduced $H$. contortus eggs by $69 \%$ per $g$ of feces in artificially infected sheep (24). Similarly, 95\% reduction of the gastrointestinal nematode infective larvae population in fecal cultures was obtained through the oral administration of an aqueous extract of a combination of Mentha piperita and Chenopodium ambrosioides in goats (25). The selected plant extracts assessed in the present study should be evaluated using sheep and other economically important species as possible potential natural compounds to be used in integrated control programs. The use of this technology could lead to the development of environmental friendly alternatives for the control of gin and can be used with other ecological measures to substantially reduce the parasitic burdens in animals and improve both animal health and production (26). The results of the present study show that the combined use of both plant extracts produces a higher anthelmintic effect than the use of the individual plant extracts. In this regard, such an increased activity could be due to either a synergic or additive effect achieved when the bio-compounds present in the two plant extracts have an interaction that leads to a higher anti-parasitic effect (27).

\section{CONCLUSIONS}

The nematocidal activity of the $A$. sativum hexane extract was demonstrated against $H$. contortus when administered in jirds (Meriones spp.) either alone or combined with $T$. erecta acetone extracts. The use of selected plant extracts with an anthelmintic activity offers a viable and sustainable alternative to be used as an integrated bio-control system against parasitic gin in economically important animal species. Obtaining plant extracts with the highest anthelmintic activity is an important alternative to obtain a natural product that replaces, at least partially, the use of chemical drugs against animal parasitic nematodes.

Ethics Committee Approval: Approved by the Ethical Committee of INIFAP-Mexico, strictly following the Federal Law and Official Rule number (NOM-051-ZOO-1995), endorsed by the maximum authority at CENID-Parasitología Veterinaria, INIFAP Dr. Julio Figueroa Millán, Director in charge.

Informed Consent: Not required in this study.

Peer-review: Externally peer-reviewed.

Author contributions: Concept - P.M.G., D.O.S.S., M.G.V.C.; Design M.E.L.A., E.L.H.; Supervision - P.M.G.; Funding - P.M.G.; Materials P.M.G.; Data Collection and/or Processing - J.P.L., E.L.H.; Analysis and/or Interpretation - V.M.H.V., J.P.L.; Literature Review - J.P.L.; Writer - P.M.G, M.G.V.C.; Critical Review - P.M.G., M.G.V.C.

Conflict of Interest: No conflict of interest was declared by the authors.

Acknowledgment: The authors would like to thank the kind financial support by CONACYT Mexico PROJECT: CONACYT-SAGARPA - 2004c01-78.

Financial Disclosure: This study was financially supported by CENIDParasitología Veterinaria INIFAP-Mexico and CONACYT Mexico Project: CONACYT-SAGARPA - 2004-CO1-78.
Etik Komite Onayı: INIFAP'ın Sorumlu Müdürü Dr. Julio Figueroa Millán, CENID-Parasitología Veterinaria tarafından onaylanıp Federal Yasa ve Resmi Yönetmelik numarasını (NOM-051-ZOO-1995) uygulayarak, INIFAP-Mexico'dan etik komite onayı alınmıştır.

Hasta Onamı: Bu çalışma için hasta onamına gerek yoktur.

Yazar Katkıları: Fikir - P.M.G., D.O.S.S., M.G.V.C.; Tasarim - M.E.L.A., E.L.H.; Denetleme - P.M.G.; Kaynaklar - P.M.G.; Malzemeler - P.M.G.; Veri Toplanması ve/veya işlemesi - J.P.L.; E.L.H.; Analiz ve/veya Yorum V.M.H.V., J.P.L.; Literatür taraması - J.P.L.; Yazıyı Yazan - P.M.G.; M.G.V.C.; Eleştirel İnceleme - P.M.G., M.G.V.C.

Teşekkür: Yazarlar, bu çalışmayı destekleyen CONACYT Meksika Projesi: CONACYT-SAGARPA - 2004-CO1-78 teşekkür eder.

Hakem Değerlendirmesi: Dış Bağımsız.

Çıkar Çatışması: Yazarlar çıkar çatışması bildirmemişlerdir.

Finansal Destek: Bu çalışma CENID-Parasitologia Veterinaria INIFAPMexico ve CONACYT Mexico Proje: CONACYT-SAGARPA - 2004-CO178 kodlu proje tarafından desteklenmiştir.

\section{REFERENCES}

1. Poglaven G, Battelli G. An insight into the epidemiology and economic impact of gastro-intestinal nematodes in small ruminants. Parassitologia 2006; 48: 409-13.

2. Macedo-Barragán R, Arredondo-Ruiz V, Ramírez-Rodríguez J, García-Márquez LJ. Grazing sheep poisoned by milkweed Asclepias curassavica or gastrointestinal nematosis? A case report findings. Vet Méx 2009; 40: 275-81.

3. Jensen J, Henning, KP, Sverdrup EL. Effects of the antibacterial agents tiamulin, olanquindox and metronidazole and the anthelmintic ivermectin on the soil invertebrate species Folsomia fimetaria (Collembola) and Enchytraeus crypticus (Enchytraeidae). Chemosphere 2003; 50: 3: 437-443. [CrossRef]

4. Pyakuryal B. A feasibility study on the application of green technology for sustainable agriculture development: Assessing the policy impact in selected member countries of ESCAP-APCAEM. United Nations. 2012;117 p. http://www.unapcaem.org/publication/GreenTech.pdf

5. Githiori JB, Athanasiadou S, Thamsborg SM. Use of plants in novel approaches for control of gastrointestinal helminths in livestock with emphasis on small ruminants. Vet Parasitol 2006; 139: 308-20. [CrossRef]

6. López-Aroche U, Salinas-Sánchez OD, Mendoza de Gives P, López-A MaE, Liébano-Hernández E, Valladares-Cisneros MG, et al. In vitro nematicidal effect of medicinal plants from "Sierra de Huautla", Biosphere Reserve, Morelos, Mexico against Haemonchus contortus infective larvae. J Helminthol 2008; 81: 1-8. [CrossRef]

7. Rockfort S, Parker JA, Dunshea RF. Plant bio-actives for ruminant health and productivity. Phytochemistry 2008; 69: 299-322. [CrossRef]

8. Aguilar HH, de Gives PM, Sánchez DO, Arellano ME, Hernández EL, Aroche UL, et al. In vitro nematicidal activity of plant extracts of the Mexican flora against Haemonchus contortus fourth larval stage. Ann N Y Acad Sci 2008; 1149: 158-60. [CrossRef]

9. Shai LJ, Bizimenyera ES, Bagla V, McGaw LJ, Eloff JN. Curtisia dentate (Cornaceae) leaf extracts and isolated compounds inhibit motility of parasitic and free-living nematodes. Onderstepoort J Vet Res 2009; 76: 2: 249-56. [CrossRef]

10. Alonso-Díaz MA, Torres-Acosta JFJ, Sandoval-Castro CA, Hoste H. Tannins in tropical tree fodders fed to small ruminants: A friendly foe? Small Rumin Res 2010; 89: 164-73. [CrossRef]

11. Block E. Garlic and Other Alliums: The Lore and the Science. New York, USA. RSC, 2010.

12. Dharmagadda V, Naik SN, Mittal PK, Vasudevan P. Larvicidal activity of Tagetes patula essential oil against three mosquito species. BioresourTechnol 2005; 96: 1235-40 [CrossRef] 
13. Farjana N, Rowshanul HM, Zahangir AS, Rezaul MK, Apurba KR, Shahriar Z. Toxicological evaluation of chloroform fraction of flower of Tagetes erecta Linn on rats. Int J Drug Dev \& Res 2009; 1: 1: 161-165.

14. Ghani A. Medicinal plants of Bangladesh: Chemical constituents and uses, 2nd edition, Dhaka, India. Asiatic Society of Bangladesh, 2003.

15. Krueger R, Dover EK, McSorley R, Wang KH. Marigold (Tagetes spp) for nematode management. University of Florida IFAS, 2009.

16. Kuklisnki C. Farmacognosia. 2da Ed, Barcelona, Espa-a. Edit. Omega. 2000.

17. De Jesús-Gabino AF, Mendoza-de Gives P, Salinas-Sánchez DO, López-Arellano ME, Liébano-Hernandez E, Hernández-Velázquez VM, et al. Anthelmintic effects of Prosopis leavigata n-hexanic extract against Haemonchus contortus in artificially infected gerbils (Meriones unguiculatus). J Helminthol 2010, 84: 71-5. [CrossRef]

18. Chaney A. Identification of Internal Parasites of Sheep and Goats. Honors College, 2012, Paper 26. http://digitalcommons.library.umaine.edu/honors/26

19. Mendoza de Gives P, Flores Crespo J, Herrera Rodriguez D, Vázquez Prats V, Liébano Hernandez E, Ontiveros Fernandez GE. Biological control of Haemonchus contortus infective larvae in ovine faeces by administering an oral suspension of Duddingtonia flagrans chlamydospores to sheep. J Helminthol 1998; 72: 343-7. [CrossRef]

20. Zar, JH. Biostatistical Analysis. Fourth Edition, Illinois, USA. Prentice Hall. 1998.
21. SAS, Institute. Language guide for personal computer release. 6.03 Edition. North Carolina. USA. SAS Institute. Cary, 1998.

22. VICH. Efficacy of anthelmintics: specific recommendations for bovines. International Cooperation on Harmonisation of Technical Requirements for Registration of Veterinary Medicinal Products. VICH Guideline 12 (Anthelminticas: Bovines), November, 1999. For Implementation at Step 7. 1-6.

23. Jegede OC, Ajanusi JO, Adaudi AO, Agbede RI. Anthelmintic efficacy of extracts of Spigelia anthelma Linn on experimental Nippostrongylus braziliensis in rats. J Vet Sci 2006; 7: 229-32. [CrossRef]

24. Komen C, Wanjala MF, Kiprono CP. Eficacy of Jasminum abyssinicum treatment against Haemonchus contortus in sheep. Afr J Tradit Complement Altern Med 2005, 2: 3: 264-68.

25. De Almeida MA, Domingues LF, Almeida GN, Simas MM, Botura MB, Da Cruz AC, et al. Effects of aqueous extracts of Mentha piperita $L$. and Chenopodium ambrosioides $L$. leaves in infective larvae cultures of gastrointestinal nematodes of goats. Rev Bras Parasitol Vet 2007; 16: 57-9.

26. Wangchuk P. Health Impacts of traditional medicines and bio-prospecting: A World scenario accentuating Bhutan's perspective. J Bhutan Studies 2008, 18: 116-34.

27. Gathirwa JW, Rukunga GM, Njagi EN, Omar SA, Mwitari PG, Guantai $A N$, et al. The in vitro anti-plasmodial and in vivo anti-malaria efficacy of combinations of some medicinal plants used traditionally for treatment of malaria by the Meru community in Kenya. J Ethnopharmacol 2008; 115: 223-31. [CrossRef] 